\title{
Erratum to: Governance of Eco-Labels: Expert Opinion and Media Coverage
}

\author{
Pavel Castka Charles J. Corbett
}

Published online: 20 January 2015

(C) Springer Science+Business Media Dordrecht 2015

\section{Erratum to: J Bus Ethics}

\section{DOI 10.1007/s10551-014-2474-3}

Delete the following note under Table 2: The entry " $\mathrm{n} / \mathrm{a}$ " in the correlation table indicates that the combined variable "third party audits and verifiers accredited" is never used in the same analysis as the separate variables "third-party audits" and "verifiers accredited."

The online version of the original article can be found under doi:10. 1007/s10551-014-2474-3.

\section{P. Castka $(\bowtie)$}

Department of Management, Marketing and Entrepreneurship,

University of Canterbury, Private Bag 4800, Christchurch 8140,

New Zealand

e-mail: pavel.castka@ canterbury.ac.nz

\section{J. Corbett}

UCLA Anderson School of Management, 110 Westwood Plaza,

951481, Los Angeles, CA 90095-1481, USA

e-mail: charles.corbett@anderson.ucla.edu 